\title{
THE GENOTYPIC CONTROL OF MATING SPEED AND DURATION OF COPULATION IN DROSOPHILA PSEUDO- OBSCURA
}

\author{
D. KAUL and P. A. PARSONS \\ Department of Geneties, University of Melbourne, \\ Victoria, Australio
}

Received 21.i.65

\section{INTRODUCTION}

SpEiss and Langer $\left(19^{6} 4 a\right)$ demonstrated variable mating speeds for homokaryotypes of Drosphila pseudoobscura, such that ST/ST and AR/AR karyotypes mated the most rapidly, followed by $\mathrm{CH} / \mathrm{CH}$ and TL/TL, and PP/PP was the slowest of all. Differences between karyotypes for mating speeds have also been found in $D$. persimilis (Speiss and Langer, $1964 b$ ). Such differences between karyotypes clearly argue for the great importance of mating speed as a component of fitness. This is hardly surprising, for mating speed must play an extremely important role in determining which flies will most readily transmit genes to subsequent generations.

In $D$. melanogaster, mating speed can be increased or decreased by selection (Manning, 196I), indicating a genotypic component in its determination, while Parsons (1964a, b) found strong evidence for its genotypic control based on a diallel cross for 6 inbred lines and their hybrids.

In this paper, mating speeds in $D$. pseudoobscura of 3 karyotypes, ST/ST, ST/CH and $\mathrm{CH} / \mathrm{CH}$, will be investigated. The duration of copulation will also be discussed. Speiss and Langer (1964a) used Io pairs of flies per mating chamber, but here we will follow the technique of Parsons (1964a, b), who used single pairs in a single vial, so that obtaining the duration of copulation is easy. Observations will be taken from all possible combinations between ST/ST, ST/CH and $\mathrm{CH} / \mathrm{CH}$, of which there are nine, taking into account reciprocals, so that it will be possible to determine which sex is more important in determining both mating speed and duration of copulation.

\section{METHOD}

The ST/ST, ST/CH and $\mathrm{CH} / \mathrm{CH}$ karyotypes were derived from 3 strains of ST/ST and $\mathrm{CH} / \mathrm{CH}$ karyotypes collected initially at Mather, California and maintained by Professor Th. Dobzhansky. In this laboratory they have been maintained by $\operatorname{Dr}$ J. A. Thomson.

Genetic heterogeneity was ensured by intercrossing the strains of each homokaryotype in the 3 possible ways (excluding reciprocals) in one generation, and then setting up stocks of homokaryotypes made up of equal contributions of these crosses. ST/CH flies were then produced by crossing the ST/ST and $\mathrm{CH} / \mathrm{CH}$ stocks. 
The sexes were separated at eclosion. Males and females were stored singly until they were 4 days old in vials $10 \mathrm{~cm}$. long with a diameter of $2 \frac{1}{2} \mathrm{~cm}$. A standard semolina treacle medium was used. At 4 days a single male was shaken in with a single female and observed until copulation began. The time in minutes for this to occur is the mating speed, and was recorded in $\frac{1}{2}$ minute intervals. The recording of the duration of copulation commenced as soon as copulation began. Pairs were watched for 30 minutes, and any not mating within this period were recorded as unmated.

Experiments were carried out at two levels of larval crowding, namely $4^{\circ}$ and 200 larva per vial, which will be termed low and high levels in the remainder of this paper. Fifty observations were taken for each of the 9 possible karyotypic combinations at each level of crowding, making 900 observations in all.

All flies were raised and tested at $20^{\circ} \mathrm{C}$.

\section{RESULTS}

Mating was extremely quick in general, and was rather more rapid than found by Spiess and Langer ( $1964 a)$. Differences between Spiess and Langer $(1964 a)$ and the current experiments could be explained by minor differences in experimental technique, since our experiments consisted of single pair matings at $20^{\circ} \mathrm{C}$. using flies aged 4 days, whereas Spiess and Langer's (1964a) experiments were made up of 10 pairs to a mating chamber at $25^{\circ} \mathrm{C}$. using flies aged 6 days. Differences in the stocks used could be relevant, although strains derived from Mather, California were used in both series of experiments. Brown (1964) has shown the very great importance of age as a factor, using one and three day old flies derived initially from Piñon, California. He also observed extremely rapid mating speeds.

In table 1 , the number mating out of 50 in 5 minutes and the number remaining unmated at 5 minutes are given for the 9 possible crosses for the two levels of crowding, with mean matings speeds. Mean mating speeds were computed by taking the 50 per cent. point from the probit transformation of the cumulative frequency distribution of per cent. mated against log. time in minutes. The reason for taking logs, is that the frequency distribution of numbers mated plotted against mating speed shows extreme leptokurtosis, which is partly but not entirely removed by taking logs. In passing it is interesting to note that many forms of gene dispersal in man and other organisms give leptokurtic distributions, and since mating is a form of gene dispersal, the parallelism is perhaps not unexpected (see various papers in Sutter (1962)).

The data for the low level of crowding are given in table $1 a$. In section (i) of the table, data for a given male karyotype with the 3 possible female karyotypes are presented, followed by data for a given female karyotype with the 3 possible male karyotypes in section (ii). Based on those mating in 5 minutes, and those not mating in 5 minutes, heterogeneity $\chi_{2}^{2}$ tests were carried out for each given male and female in turn. On the whole $\chi_{2}^{2}$ values are greater for given females than males. The lower level of heterogeneity for given males 
TABLE ]

Mating speeds

(a) Low level of crowding

\begin{tabular}{|c|c|c|c|c|c|c|c|}
\hline (i) & male & female & $\begin{array}{c}\text { Mean } \\
\text { mating } \\
\text { speed } \\
\text { minutes }\end{array}$ & $\begin{array}{l}\text { Number } \\
\text { mating in } \\
5 \text { minutes }\end{array}$ & $\begin{array}{l}\text { Number } \\
\text { remaining } \\
\text { unmated } \\
\text { at } 5 \mathrm{~min} \text {. }\end{array}$ & $\begin{array}{l}\chi_{2}^{2} \text { for } \\
\text { hetero- } \\
\text { geneity }\end{array}$ & Probability \\
\hline & $\mathrm{ST} / \mathrm{ST}$ & $\begin{array}{l}\mathrm{ST} / \mathrm{ST} \\
\mathrm{ST} / \mathrm{CH} \\
\mathrm{CH} / \mathrm{CH}\end{array}$ & $\begin{array}{l}0.75 \\
2 \cdot 11 \\
1 \cdot 50\end{array}$ & $\begin{array}{l}42 \\
38 \\
44\end{array}$ & $\begin{array}{r}8 \\
12 \\
6\end{array}$ & $2 \cdot 61$ & $0.2<\mathrm{P}<0.3$ \\
\hline & $\mathrm{ST} / \mathrm{CH}$ & $\begin{array}{l}\mathrm{ST} / \mathrm{ST} \\
\mathrm{ST} / \mathrm{CH} \\
\mathrm{CH} / \mathrm{CH}\end{array}$ & $\begin{array}{l}1 \cdot 58 \\
1 \cdot 50 \\
2 \cdot 62\end{array}$ & $\begin{array}{l}37 \\
44 \\
33\end{array}$ & $\begin{array}{r}13 \\
6 \\
17\end{array}$ & $6 \cdot 8 o$ & $<0.05$ \\
\hline & $\mathrm{CH} / \mathrm{CH}$ & $\begin{array}{l}\mathrm{ST} / \mathrm{ST} \\
\mathrm{ST} / \mathrm{CH} \\
\mathrm{CH} / \mathrm{CH}\end{array}$ & $\begin{array}{l}3.50 \\
5.50 \\
2.87\end{array}$ & $\begin{array}{l}32 \\
20 \\
31\end{array}$ & $\begin{array}{l}18 \\
30 \\
19\end{array}$ & $7 \cdot 17$ & $<0.05$ \\
\hline
\end{tabular}

(ii) female male

\begin{tabular}{|ll|l|r|r|r|r}
\hline ST/ST & ST/ST & 0.75 & 42 & 8 & 5.20 & $0.05<\mathrm{P}<0.1$ \\
& ST/CH & 1.58 & 37 & 13 & & \\
& $\mathrm{CH} / \mathrm{CH}$ & 3.50 & 32 & 18 & & \\
$\mathrm{ST} / \mathrm{CH}$ & $\mathrm{ST} / \mathrm{ST}$ & 2.11 & 38 & 12 & 28.68 & $<0.001$ \\
& $\mathrm{ST} / \mathrm{CH}$ & 1.50 & 44 & 6 & & \\
& $\mathrm{CH} / \mathrm{CH}$ & 5.50 & 20 & 30 & & \\
& & & & & \\
$\mathrm{CH} / \mathrm{CH}$ & $\mathrm{ST} / \mathrm{ST}$ & 1.50 & 44 & 6 & 9.72 & \\
& $\mathrm{ST} / \mathrm{CH}$ & 2.62 & 33 & 17 & & \\
& $\mathrm{CH} / \mathrm{CH}$ & 2.87 & 31 & 19 & & \\
& & & & & & \\
\hline
\end{tabular}

(iii) Pooled data from (i) and (ii) $\chi_{1}^{2}$

\begin{tabular}{|c|c|c|c|c|c|c|}
\hline \multirow[t]{3}{*}{ males } & $\begin{array}{l}\text { ST/ST } \\
\text { ST } / C H\end{array}$ & $\begin{array}{r}1.47 \\
1.83\end{array}$ & 124 & 26 & $1 \cdot 65$ & $0.1<\mathrm{P}<0.2$ \\
\hline & $\begin{array}{l}\mathrm{ST} / \mathrm{ST} \\
\mathrm{CH} / \mathrm{CH}\end{array}$ & $\begin{array}{l}1 \cdot 47 \\
4 \cdot 22\end{array}$ & $\begin{array}{r}124 \\
83\end{array}$ & $\begin{array}{l}26 \\
67\end{array}$ & $24 \cdot 93$ & $<0.001$ \\
\hline & $\begin{array}{l}\mathrm{ST} / \mathrm{CH} \\
\mathrm{CH} / \mathrm{CH}\end{array}$ & $\begin{array}{l}1 \cdot 83 \\
4 \cdot 22\end{array}$ & $\begin{array}{r}114 \\
83\end{array}$ & $\begin{array}{l}36 \\
67\end{array}$ & $13 \cdot 31$ & $<0.001$ \\
\hline \multirow[t]{3}{*}{ females } & $\begin{array}{l}\text { ST/ST } \\
\text { ST/CH }\end{array}$ & $\begin{array}{l}1 \cdot 67 \\
2 \cdot 33\end{array}$ & $\begin{array}{l}\text { II I } \\
\text { I02 }\end{array}$ & $\begin{array}{l}39 \\
48\end{array}$ & $1 \cdot 04$ & $0.3<\mathrm{P}<0.5$ \\
\hline & $\begin{array}{l}\mathrm{ST} / \mathrm{ST} \\
\mathrm{CH} / \mathrm{CH}\end{array}$ & $\begin{array}{l}1 \cdot 67 \\
2 \cdot 30\end{array}$ & $\begin{array}{l}111 \\
108\end{array}$ & $\begin{array}{l}39 \\
42\end{array}$ & 0.07 & $0.7<P<0.8$ \\
\hline & $\begin{array}{l}\mathrm{ST} / \mathrm{CH} \\
\mathrm{CH} / \mathrm{CH}\end{array}$ & $\begin{array}{l}2 \cdot 33 \\
2 \cdot 30\end{array}$ & $\begin{array}{l}102 \\
108\end{array}$ & $\begin{array}{l}4^{8} \\
4^{2}\end{array}$ & 0.40 & $0.5<\mathrm{P}<0.7$ \\
\hline
\end{tabular}


TABLE I

Mating speeds

(b) High level of crowding

\begin{tabular}{|c|c|c|c|c|c|c|c|}
\hline (i) & male & female & $\begin{array}{l}\text { Mean } \\
\text { mating } \\
\text { speed } \\
\text { minutes }\end{array}$ & $\begin{array}{l}\text { Number } \\
\text { mating in } \\
5 \text { minutes }\end{array}$ & $\begin{array}{l}\text { Number } \\
\text { remaining } \\
\text { unmated } \\
\text { at } 5 \mathrm{~min} \text {. }\end{array}$ & $\begin{array}{l}\chi_{2}^{2} \text { for } \\
\text { hetero- } \\
\text { geneity }\end{array}$ & Probability \\
\hline & ST/ST & $\begin{array}{l}\mathrm{ST} / \mathrm{ST} \\
\mathrm{ST} / \mathrm{CH} \\
\mathrm{CH} / \mathrm{CH}\end{array}$ & $\begin{array}{l}3 \cdot 09 \\
2 \cdot 50 \\
2 \cdot 82\end{array}$ & $\begin{array}{l}37 \\
34 \\
30\end{array}$ & $\begin{array}{l}13 \\
16 \\
20\end{array}$ & $2 \cdot 24$ & $0.3<\mathrm{P}<0.5$ \\
\hline & $\mathrm{ST} / \mathrm{CH}$ & $\begin{array}{l}\mathrm{ST} / \mathrm{ST} \\
\mathrm{ST} / \mathrm{CH} \\
\mathrm{CH} / \mathrm{CH}\end{array}$ & $\begin{array}{l}2 \cdot 59 \\
2 \cdot 74 \\
3 \cdot 16\end{array}$ & $\begin{array}{l}38 \\
36 \\
33\end{array}$ & $\begin{array}{l}12 \\
14 \\
17\end{array}$ & $I \cdot 24$ & $0.5<\mathrm{P}<0.7$ \\
\hline & $\mathrm{CH} / \mathrm{CH}$ & $\begin{array}{l}\mathrm{ST} / \mathrm{ST} \\
\mathrm{ST} / \mathrm{CH} \\
\mathrm{CH} / \mathrm{CH}\end{array}$ & $\begin{array}{l}6 \cdot 29 \\
3 \cdot 78 \\
6 \cdot 00\end{array}$ & $\begin{array}{l}21 \\
27 \\
22\end{array}$ & $\begin{array}{l}29 \\
23 \\
28\end{array}$ & I. 66 & $0.3<P<0.5$ \\
\hline (ii) & female & \multicolumn{6}{|l|}{ male } \\
\hline & $\mathrm{ST} / \mathrm{ST}$ & $\begin{array}{l}\mathrm{ST} / \mathrm{ST} \\
\mathrm{ST} / \mathrm{CH} \\
\mathrm{CH} / \mathrm{CH}\end{array}$ & $\begin{array}{l}3 \cdot 09 \\
2 \cdot 59 \\
6 \cdot 29\end{array}$ & $\begin{array}{l}37 \\
38 \\
21\end{array}$ & $\begin{array}{l}13 \\
12 \\
29\end{array}$ & $15 \cdot 80$ & $\mathrm{P}<0.001$ \\
\hline & $\mathrm{ST} / \mathrm{CH}$ & $\begin{array}{l}\text { ST/ST } \\
\text { ST/CH } \\
\mathrm{CH} / \mathrm{CH}\end{array}$ & $\begin{array}{l}2 \cdot 50 \\
2 \cdot 74 \\
3 \cdot 78\end{array}$ & $\begin{array}{l}34 \\
36 \\
27\end{array}$ & $\begin{array}{l}16 \\
14 \\
23\end{array}$ & $3 \cdot 9 !$ & $0.1<\mathrm{P}<0.2$ \\
\hline & $\mathrm{CH} / \mathrm{CH}$ & $\begin{array}{l}\mathrm{ST} / \mathrm{ST} \\
\mathrm{ST} / \mathrm{CH} \\
\mathrm{CH} / \mathrm{CH}\end{array}$ & $\begin{array}{l}2 \cdot 82 \\
3 \cdot 16 \\
6 \cdot 00\end{array}$ & $\begin{array}{l}30 \\
33 \\
22\end{array}$ & $\begin{array}{l}20 \\
17 \\
28\end{array}$ & $5 \cdot 27$ & $0.05<\mathrm{P}<0.1$ \\
\hline \multicolumn{5}{|c|}{ (iii) Pooled data from (i) and (ii) } & \multicolumn{3}{|c|}{$\chi_{1}^{2}$} \\
\hline \multirow{3}{*}{\multicolumn{2}{|c|}{ males }} & $\begin{array}{l}\text { ST/ST } \\
\text { ST/CH }\end{array}$ & $\begin{array}{l}2 \cdot 88 \\
2 \cdot 77\end{array}$ & $\begin{array}{l}101 \\
107\end{array}$ & $\begin{array}{l}49 \\
43\end{array}$ & 0.39 & $0.5<\mathrm{P}<0.7$ \\
\hline & & $\begin{array}{l}\mathrm{ST} / \mathrm{ST} \\
\mathrm{CH} / \mathrm{CH}\end{array}$ & $\begin{array}{l}2 \cdot 88 \\
5 \cdot 50\end{array}$ & $\begin{array}{r}101 \\
70\end{array}$ & $\begin{array}{l}49 \\
80\end{array}$ & $12 \cdot 24$ & $<0.001$ \\
\hline & & $\begin{array}{l}\mathrm{ST} / \mathrm{CH} \\
\mathrm{CH} / \mathrm{CH}\end{array}$ & $\begin{array}{l}2 \cdot 77 \\
5 \cdot 50\end{array}$ & $\begin{array}{r}107 \\
70\end{array}$ & $\begin{array}{l}43 \\
80\end{array}$ & $17 \cdot 86$ & $<0.001$ \\
\hline \multirow{3}{*}{\multicolumn{2}{|c|}{ females }} & $\begin{array}{l}\text { ST/ST } \\
\text { ST/CH }\end{array}$ & $\begin{array}{l}3 \cdot 33 \\
3 \cdot 00\end{array}$ & $\begin{array}{l}96 \\
85\end{array}$ & $\begin{array}{l}54 \\
65\end{array}$ & $1 \cdot 39$ & $0.2<\mathrm{P}<0.3$ \\
\hline & & $\begin{array}{l}\mathrm{ST} / \mathrm{ST} \\
\mathrm{CH} / \mathrm{CH}\end{array}$ & $\begin{array}{l}3 \cdot 33 \\
3 \cdot 57\end{array}$ & $\begin{array}{l}96 \\
97\end{array}$ & $\begin{array}{l}54 \\
53\end{array}$ & 0 & $>0.9$ \\
\hline & & $\begin{array}{l}\mathrm{ST} / \mathrm{CH} \\
\mathrm{CH} / \mathrm{CH}\end{array}$ & $\begin{array}{l}3.00 \\
3.57\end{array}$ & $\begin{array}{l}97 \\
85\end{array}$ & $\begin{array}{l}53 \\
65\end{array}$ & $1 \cdot 69$ & $0 . \mathrm{r}<\mathrm{P}<0.2$ \\
\hline
\end{tabular}


indicates that the male is more important than the female in determining the number mating in 5 minutes.

Even though there is some heterogeneity for ST/ST and $\mathrm{CH} / \mathrm{CH}$ in section (i) of the table, the data for each given male are pooled, and then pairs of given males are compared with each other by $2 \times 2$ contingency $\chi^{2}$ tests in section (iii) of the table. It is clear that the ST/ST and ST/CH karyotypes are equivalent for the number mating in 5 minutes, while the $\mathrm{CH} / \mathrm{CH}$ karyotype is significantly slower. This is confirmed by the mean mating speeds. It is reassuring that Spiess and Langer ( $1964 a$ ) found that the ST/ST karyotypes mated more rapidly than the $\mathrm{CH} / \mathrm{CH}$ karyotypes. Pooling the data for given females does not, however, lead to marked differences between karyotypes.

In table $i b$, results for the high level of crowding are presented. On the whole there are rather fewer matings in 5 minutes, and the mating speeds are slower than in table $1 a$. The data for given males in table $\mathrm{I} b$ do not show significant heterogeneity, while, as in table I $a$, the $\chi_{2}^{2}$ values for the given females are all higher than for given males, and some indicate significant heterogeneity. Similarly, as at the low level of crowding, the $2 \times 2$ contingency $\chi^{2}$ tests show that more $\mathrm{ST} / \mathrm{ST}$ and $\mathrm{ST} / \mathrm{CH}$ males mate in 5 minutes than $\mathrm{CH} / \mathrm{CH}$, but with little difference between female karyotypes.

The data in sections (i) and (ii) of tables $\mathrm{I} a$ and $b$ can be reorganised into a $3 \times 3$ diallel cross. This is a convenient starting point for analyses of variance. Since the data consist of proportions or percentages of successful matings out of 50 in 5 minutes, the angular transformation

$$
p=\sin ^{2} \phi
$$

where $p=$ percentage of successful matings, and $\phi$ is an angle from o to $90^{\circ}$, was applied before carrying out the analyses of variance (Fisher, I949; Parsons, I964a). The variances of $\phi$ will then be independent of the means, and will depend on the sample size (50) on which an observation is based.

Wearden (1964) summarised a series of methods for the analysis of diallel crosses proposed by several authors. One of the analyses separates out variation due to maternal and paternal karyotypes, and carrying this out (table 2) shows the predominant influence of the karyotype of the males in determining the number mating in 5 minutes.

In table 3 is an analysis of variance given by Wearden (see the Hayman analysis in table 4 of his paper) based on a model for maternal (or paternal) effects, which tests, among other things, whether one sex has a greater contribution than the other. Relative to the error, the m.s. for parental lines $(a)$ and paternal effects $(c)$ are very large. A strict test for parental lines is the ratio of the m.s. for $(a)$ to that for (c) which comes to $\mathrm{I} \cdot 8 \mathrm{I}$, showing that paternal effects account for a great deal of the effects due to parental lines. 
The component for interactions between karyotypes is nonsignificant, whether by comparison with the error m.s. or the reciprocal

TABLE 2

Analysis of variance of the number mating out of 50 in 5 minutes

(after applying the angular transformation)

\begin{tabular}{|c|c|c|c|c|}
\hline Source of variation & d.f. & m.s. & $\mathbf{F}$ & Probability \\
\hline $\begin{array}{l}\text { Females } \\
\text { Males } \\
\text { Replicates (crowding levels) } \\
\text { Error }\end{array}$ & $\begin{array}{r}2 \\
2 \\
1 \\
12\end{array}$ & $\begin{array}{r}\text { I I } 5 \\
412 \cdot 0 \\
\text { I } 75 \cdot 5 \\
32 \cdot 1\end{array}$ & $\begin{array}{r}0 \cdot 36 \\
12 \cdot 84 \\
5 \cdot 47\end{array}$ & $\begin{array}{l}\mathrm{P}<0.01 \\
\mathrm{P}<0.05\end{array}$ \\
\hline
\end{tabular}

TABLE 3

Analysis of variance of the number mating out of 50 in 5 minutes (after applying the angular transformation) for a model including a component for paternal effects

\begin{tabular}{|c|c|c|c|c|}
\hline Source of variation & d.f. & m.s. & F & Probability \\
\hline $\begin{array}{l}\text { (a) Parental lines } \\
\text { (b) Interactions between karyotypes } \\
\text { (c) Paternal effects } \\
\text { (d) Reciprocal effects. } \\
\text { Replicates (crowding levels) } \\
\text { Error }\end{array}$ & $\begin{array}{l}2 \\
3 \\
2 \\
1 \\
1 \\
8\end{array}$ & $\begin{array}{r}272 \cdot 6 \\
34 \cdot 2 \\
150 \cdot 8 \\
6 \cdot 2 \\
175 \cdot 5 \\
34 \cdot 5\end{array}$ & $\begin{array}{l}7 \cdot 90 \\
0 \cdot 99 \\
4 \cdot 37 \\
0 \cdot 18 \\
5 \cdot 08 \\
\cdots\end{array}$ & $\begin{array}{l}<0.05 \\
\ldots 0.10 \\
<0.10 \\
<0 \\
\cdots\end{array}$ \\
\hline
\end{tabular}

effects m.s. $(d)$. This means that differences in the number mating in 5 minutes are due to the karyotypes themselves, and that there are no significant behavioural interactions between karyotypes.

TABLE 4

Number mating out of 50 in 30 minutes

\begin{tabular}{|c|c|c|c|c|c|c|c|c|}
\hline $\begin{array}{l}\text { Larval crowding } \\
\text { level }\end{array}$ & \multicolumn{4}{|c|}{ Low } & \multicolumn{4}{|c|}{ High } \\
\hline Male parent & $\mathrm{ST} / \mathrm{ST}$ & $\mathrm{ST} / \mathrm{CH}$ & $\mathrm{CH} / \mathrm{CH}$ & Totals & $\mathrm{ST} / \mathrm{ST}$ & $\mathrm{ST} / \mathrm{CH}$ & $\mathrm{CH} / \mathrm{CH}$ & Totals \\
\hline $\begin{array}{l}\text { Female parent } \\
\text { ST/ST } \\
\text { ST/CH } \\
\mathrm{CH} / \mathrm{CH}\end{array}$ & $\begin{array}{l}50 \\
45 \\
46\end{array}$ & $\begin{array}{l}48 \\
49 \\
45\end{array}$ & $\begin{array}{l}47 \\
41 \\
42\end{array}$ & $\begin{array}{r}145 \\
135 \\
133\end{array}$ & $\begin{array}{l}45 \\
45 \\
43\end{array}$ & $\begin{array}{l}45 \\
42 \\
46\end{array}$ & $\begin{array}{l}39 \\
41 \\
44\end{array}$ & $\begin{array}{l}129 \\
128 \\
133\end{array}$ \\
\hline Totals . & 141 & 142 & 130 & $4^{13}$ & 133 & 133 & 124 & 390 \\
\hline
\end{tabular}

In table 4 , the numbers mating out of 50 in 30 minutes are given. Except in the case of ST/ST $+\times \mathrm{CH} / \mathrm{CH} \approx$ at the high level of crowding, where there were 39 matings, there are $>40$ matings throughout. Analyses of variance as presented in tables 2 and 3 were carried out on these data, but with generally insignificant results, 
as might be expected because all observations were so close to 50 . Thus the main differential effect of the karyotypes on mating speed

TABLE 5

Mean durations of copulation (minutes)

(a) Low level of crowding

\begin{tabular}{|l|l|l|l|l|l|}
\hline \multicolumn{2}{|c|}{ male parent } & ST/ST & ST/CH & CH/CH & \\
\hline \multirow{2}{*}{ female } & ST/ST & 4.45 & 4.37 & 3.14 & 3.99 \\
parent & ST/CH & 5.56 & $4 \cdot 4 \mathrm{I}$ & 3.49 & 4.49 \\
& CH/CH & 6.10 & 4.54 & 3.27 & 4.64 \\
& & & & & \\
& & 5.37 & 4.44 & 3.30 & 4.37 \\
\hline
\end{tabular}

(b) High level of crowding

\begin{tabular}{|c|c|c|c|c|c|}
\hline \multicolumn{2}{|c|}{ male parent } & ST/ST & ST/CH & CH/CH & \\
\hline female & ST/ST & $5 \cdot 72$ & 4.06 & $3 \cdot 19$ & $4 \cdot 32$ \\
parent & ST/CH & 5.41 & $4 \cdot 53$ & $4 \cdot 15$ & 4.70 \\
& CH/CH & $5 \cdot 79$ & $4 \cdot 23$ & $3 \cdot 83$ & $4 \cdot 62$ \\
& & & & & \\
& & 5.64 & 4.27 & 3.73 & 4.55 \\
\hline
\end{tabular}

(c) Combined means from $a$ and $b$

\begin{tabular}{|c|c|c|c|c|c|}
\hline \multicolumn{2}{|c|}{ male parent } & ST/ST & ST/CH & CH/CH & \\
\hline female & ST/ST & 5.08 & $4 \cdot 22$ & $3 \cdot 17$ & $4 \cdot 16$ \\
parent & ST/CH & 5.49 & $4 \cdot 47$ & $3 \cdot 82$ & 4.59 \\
& CH/CH & 5.95 & 4.38 & 3.55 & 4.63 \\
& & & & & \\
& & 5.51 & 4.36 & 3.51 & 4.46 \\
\hline
\end{tabular}

Difference between means (using error variance in table 6 for significance tests)

\begin{tabular}{|c|c|c|}
\hline Contrasts & Females & Males \\
\hline ST/ST-ST/CH & $-0.44^{* * *}$ & $1 \cdot 15^{* * *}$ \\
ST/ST-CH/CH & $-0.47^{* * *}$ & $1 \cdot 99^{* * *}$ \\
ST/CH-CH/CH & -0.04 & $0.84^{* * *}$ \\
\hline & & \\
\hline
\end{tabular}

occurs over quite a short period. The main effect is in fact in the period from o to 15 minutes.

In table 5, the mean durations of copulation are presented for both levels of crowding, with combined values. In tables 6 and 7 
analyses of variance are presented. The analyses of variance are based on durations of copulation for 39 matings for each of the 18 possible contrasts. This is because, as shown in table 4 , the number of matings for each contrast is $\geqq 39$, so that to carry out a simple analysis of variance, the number of observations was reduced to 39 in all cases by removing the excess over 39 by a randomisation procedure. This

TABLE 6

Analysis of variance of durations of copulation

\begin{tabular}{|c|c|c|c|c|}
\hline Source of variation & d.f. & m.s. & F & Probability \\
\hline $\begin{array}{l}\text { Females } \\
\text { Males } \\
\text { Replicates (crowding levels) } \\
\text { Females } \times \text { males } \\
\text { Females } \times \text { replicates } \\
\text { Males } \times \text { replicates } \\
\text { Females } \times \text { males } \times \text { replicates }\end{array}$ & $\begin{array}{l}2 \\
2 \\
1 \\
4 \\
2 \\
2 \\
4\end{array}$ & $\begin{array}{r}16 \cdot 2 \\
23 \cdot 3 \\
5 \cdot 5 \\
4 \cdot 1 \\
1 \cdot 9 \\
5 \cdot 5 \\
8 \cdot 1\end{array}$ & $\begin{array}{r}9 \cdot 30 \\
134 \cdot 86 \\
3 \cdot 15 \\
2 \cdot 35 \\
1 \cdot 09 \\
3 \cdot 19 \\
4 \cdot 64\end{array}$ & 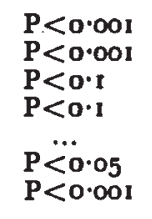 \\
\hline Error & 684 & $1 \cdot 7$ & & \\
\hline
\end{tabular}

leads to a loss of $\mathrm{I} 3$ per cent. of the data, but the simplicity of analysis outweighs this disadvantage.

In table 6 , the analysis of variance separating out variation due to maternal and paternal karyotypes is given, and shows, as for the number mating in 5 minutes, the predominant influence of the male

TABLE 7

Analysis of variance of durations of copulation for a model including a component for paternal effects

\begin{tabular}{|c|c|c|c|c|}
\hline Source of variation & d.f. & m.s. & $\mathbf{F}$ & Probability \\
\hline $\begin{array}{l}\text { (a) Parental lines } \\
\text { (b) Interactions between karyotypes } \\
\text { (c) Paternal effects } \\
\text { (d) Reciprocal effects } \\
\text { Replicates (crowding levels) }\end{array}$ & $\begin{array}{l}2 \\
3 \\
2 \\
1 \\
1\end{array}$ & $\begin{array}{r}67 \cdot 8 \\
1.5 \\
182 \cdot 7 \\
11 \cdot 7 \\
5 \cdot 5\end{array}$ & $\begin{array}{r}37 \cdot 97 \\
0.86 \\
102 \cdot 32 \\
6 \cdot 55 \\
3 \cdot 07\end{array}$ & $\begin{array}{l}P<0.001 \\
P<0.001 \\
P<0.05 \\
P<0.1\end{array}$ \\
\hline Error . & 692 & 1.8 & & \\
\hline
\end{tabular}

karyotypes as opposed to female karyotypes, although the $\mathbf{F}$ value for female karyotypes is significant. Various interaction components are also significant. The significance levels given to the differences between means in table $5 c$ are based on the error m.s. in this analysis. The differences between karyotypes are far greater in males than in females as expected. It is interesting that the male karyotype $\mathrm{CH} / \mathrm{CH}$, with the shortest duration of copulation, has the longest mating speed (table I).

In table 7 , an analysis of variance is presented using the same model as in table 3. As for the number mating in 5 minutes, the 
m.s. for parental lines $(a)$ and the m.s. for paternal effects $(c)$ are very large compared with the error m.s., and the ratio of the m.s. for $(a)$ to that for $(c)$ comes to 0.37 showing that paternal effects account for most of the effects due to parental lines. As before, the m.s. for interactions between karyotypes is not significant, indicating that the duration of copulation is controlled by the karyotypes themselves, and that there are no significant behavioural interactions between karyotypes.

\section{DISCUSSION}

It might be expected that if different karyotypes differ somewhat in behaviour pattern, then there may be behavioural interactions between karyotypes. However, analyses of variance, both for the number mating in 5 minutes and duration of copulation, show that overall behaviour is determined by the karyotypes themselves without interactions between them. Parsons (1965) obtained analogous results from all possible combinations between five inbred lines of $D$. melanogaster, even though in $D$. melanogaster mating was much slower, so that minor variations in courtship behaviour could perhaps be more important and so lead to interactions.

The great importance of the karyotype of the male, as opposed to the female, in determining mating speed is clear. This accords with results from a series of combinations between inbred lines in $D$. melanogaster, where the male genotype was of critical importance, with only slightly suggestive evidence for the importance of the female's reaction to the male's courtship at slower speeds (Parsons, 1965). Mating in the experiments on $D$. pseudoobscura under discussion in this paper is so rapid that there would seem to be little time in which the female's reactions could become relevant. In $D$. persimilis it has been shown that the females are important in the control of mating speed over a one hour period for various combinations of karyotypes, due to an interaction between copulation and avoidance tendencies (Speiss and Langer, 1964b). However, after 24 hours significant differences were noted for male mating propensity as measured by the numbers of females inseminated as scored by dissection tests (Speiss and Langer, I96r).

In any case, the relative importance of the sexes will depend on the behavioural components determining mating speed, and since these differ between species (Spieth, 1952), exact correspondences between species are unlikely. Furthermore, few karyotypes have been studied in detail in $D$. pseudoobscura and $D$. persimilis, and those studied may not necessarily represent the average situation. Also, differences in experimental details are probably very important in behaviour experiments. In $D$. melanogaster, experiments studying the mating behaviour of flies without antennæ and wings clearly show the importance of the antennæ in females, and the wings of the males in courtship behaviour (Mayr, I950; Bastock, 1956). A 
consideration of experiments in other species of Drosophila, in particular D. pseudoobscura, reveal similar results (see Brown, I964), but more work would be worthwhile.

The male is also the predominant influence in the duration of copulation experiments reported in this paper, although there is a smaller significant female effect. It seems reasonable that the female does not have a greater influence.

In table 8, the sum of the mating speeds and durations of copulation for the three karyotypes in both sexes are presented, showing for the males, but not the females, a clear inverse relationship between duration of copulation and mating speed. In fact, the correlation coefficient between the 18 mating speeds in sections (i) or (ii) of

TABLE 8

Comparison of mean mating speeds and durations of copulation (minutes)

\begin{tabular}{|c|c|c|c|c|c|c|}
\hline \multirow{2}{*}{ Karyotypes } & \multicolumn{3}{|c|}{ Females } & \multicolumn{3}{|c|}{ Males } \\
\cline { 2 - 7 } & $\begin{array}{c}\text { Mating } \\
\text { speed }\end{array}$ & $\begin{array}{c}\text { Duration of } \\
\text { copulation }\end{array}$ & Sum & $\begin{array}{c}\text { Mating } \\
\text { speed }\end{array}$ & $\begin{array}{c}\text { Duration of } \\
\text { copulation }\end{array}$ & Sum \\
\cline { 2 - 7 } ST/ST & 2.33 & 4.16 & 7.49 & 2.03 & 5.51 & 7.54 \\
ST/CH & 2.69 & 4.59 & 7.28 & 2.15 & 4.36 & 6.51 \\
$\mathrm{CH} / \mathrm{CH}$ & 2.65 & 4.63 & 7.28 & 4.76 & 3.51 & 8.27 \\
\hline
\end{tabular}

tables $\mathrm{I} a$ and $b$, and the durations of copulation in tables $5 a$ and $b$ came to $-0.54(\mathrm{P}<0.02)$. For both of these variables, the ST/CH heterokaryotypes occupy a position between the homokaryotypes (table 8). As expected the sums of the two variables are relatively more equal than the two components of the sums. Perhaps mating speed and duration of copulation should be regarded as two components of an integrated system controlled mainly by the males, which have a certain amount of energy to spend on courtship and copulation, so that if one component is lengthy the other is short, and vice versa. In passing, it is worth noting that a preliminary experiment in $D$. melanogaster reveals a similar trend, but more work is needed to verify it.

From the point of view of the fitness of the population, variations in mating speed and duration, of copulation must be important. In a competitive situation those male karyotypes mating most rapidly will be most likely to leave genes in the next generation. It is difficult to see that small variations in the duration of copulation would be particularly important, except in so far as the females completing copulation first would presumably have a slight advantage in selecting oviposition sites, but in any case the sum of the mating speed and 
duration of copulation is the critical component so far as this is concerned. In this respect the male heterokaryotypes have an advantage of one or two minutes over the male homokaryotypes (table 8). Thus, as for many components of fitness that have been studied in D. pseudoobscura third chromosome polymorphisms (see Dobzhansky, 1961), the heterokaryotype has an overall advantage over the homokaryotypes. In this case, the selective advantage is restricted to males, so we have a case of differential fitnesses between sexes occurring because the male karyotypes are active in determining mating speed and duration of copulation, and the females passive.

\section{SUMMARY}

1. The mating speeds and durations of copulation for all possible combinations between the three karyotypes, ST/ST, ST/CH and $\mathrm{CH} / \mathrm{CH}$, were observed in $D$. pseudoobscura for previously unmated pairs of flies aged 4 days.

2. The mating speed and duration of copulation of a given karyotype in combination with other karyotypes is dependent on the overall behaviour of the karyotype, and there are no appreciable behavioural interactions with other karyotypes.

3. The number of $\mathrm{CH} / \mathrm{CH}$ males mating in 5 minutes was significantly lower than for ST/CH and ST/ST males. There was little difference between the female karyotypes, since mating speeds were almost entirely male determined.

4. Duration of copulation was found to be mainly male determined, with the shortest durations for $\mathrm{CH} / \mathrm{CH}$ males followed by $\mathrm{ST} / \mathrm{CH}$ and ST/ST. There were some small significant differences between females, but in the reverse order.

5. There is thus a negative correlation between mating speed and duration of copulation for different karyotypes in the males. Hence the sum of these times is more equal than the component times, so that mating speed and duration of copulation may be regarded as two components of an integrated system controlled mainly by the male. The sum of the components is less for the heterokaryotypes than the homokaryotypes in males, which therefore represents an example of heterokaryotype advantage restricted to males.

Acknowledgments.-One of us (D. K.) wishes to acknowledge support from the Commonwealth of Australia Scholarship and Fellowship plan. We would also like to thank Dr J. A. Thomson for many helpful discussions, and Miss Helen Gidley for technical assistance.

\section{REFERENCES}

BASTOCK, M. 1956. A gene mutation which changes a behavior pattern. Evolution, 10, 42 I-439.

BRown, R. G. B. 1964. Courtship behaviour in the Drosophila obscura group. I. $D$. pseudoobscura. Behaviour, 23, 61-106.

Dobzhansky, тh. 1961. On the dynamics of chromosomal polymorphism in Drosophila. Symp. Roy. Ent. Soc. Lond., 1, 30-42. 
FISHER, R. A. 1949. A preliminary linkage test with agouti and undulated mice. Heredity, 3, 229-241.

ManNing, A. 1961. The effects of artificial selection for mating speed in Drosophila melanogaster. Anim. Behaviour, 9, 82-92.

MAYR, E. 1950. The role of the antenna in the mating behavior of female Drosophila. Evolution, 4, 149-154.

PARsons, P. A. I964a. A diallel cross for mating speeds in Drosophila melanogaster. Genetica, 35, 141-151.

Parsons, P. A. $1964 b$. Genotypic control of mating speeds in Drosophila melanogaster. Experientia, 20, 569-570.

Parsons, P. A. 1965. The determination of mating speeds in Drosophila melanogaster for various combinations of inbred lines. Experientia, (In Press).

SPIESS, E. B., AND LANGER, B. 1961. Chromosomal adaptive polymorphism in Drosophila persimilis. III. Mating propensity of homokaryotypes. Evolution, 15, 535-544.

SPIEss, E. B., AND LANGER, B. 1964a. Mating speed control by gene arrangements in Drosophila pseudoobscura homokaryotypes. Proc. Natl. Acad. Sci., U.S., 5 I, 1015-1019.

SPIESS, E. B., AND LANGER, B. $1964 b$. Mating speed control by gene arrangement carriers in Drosophila persimilis. Evolution, ${ }_{1} 8,430-444$.

SPIETH, H. T. 1952. Mating behavior within the genus Drosophila (Diptera). Bull. Amer. Museum Nat. Hist., 99, 399-474.

SUTTER, J. (ED.). 1962. Les Déplacements Humains. Aspects méthodologiques de leur mésure. Hachette.

WEARDEN, s. 1964. Alternative analyses of the diallel cross. Heredity, 19, 669-680. 